\title{
Karpik in the Bottle: Can Judgment Devices Explain the Demand for Fine Wine?
}

\author{
Patrick Schenk (D)
}

Received: 3 March 2020 / Accepted: 26 July 2021 / Published online: 7 September 2021

(C) The Author(s) 2021

\begin{abstract}
Processes of valuation and evaluation are especially complex and uncertain in markets for unique products. Consider the purchase of a bottle of fine wine. Each wine was produced in a certain region, on a particular soil, by a famous wine producer, employing methods handed down for centuries. How can consumers compare unique products in order to make a choice? How is a market for singular products possible? According to Lucien Karpik's economics of singularities, such markets necessarily rely on social actors and artifacts providing knowledge on how to compare unique products, called judgment devices. To systematically assess the explanatory contribution of Karpik's approach, this paper empirically tests fundamental propositions of the economics of singularities in a quantitative framework, examining the case of the demand for fine wine. The analysis provides ample support for Karpik's theory. First, wine demand is substantially correlated with the use of judgment devices. Second, the effects of judgment devices on product demand cannot be explained by information deficits, in line with the theoretical arguments. However, the analysis also reveals deviations from the theoretical expectations. Certain judgment devices prove more important for the demand for higher priced wines than predicted, whereas others play a more minor role. Furthermore, the use of judgment devices is substantially linked to social distinction, something Karpik's theory overlooks.
\end{abstract}

Keywords Economics of singularities - Valuation and evaluation - Consumption · Uncertainty · Distinction

P. Schenk $(\bowtie)$

Soziologisches Seminar, Universität Luzern

Frohburgstrasse 3, 6002 Luzern, Switzerland

E-Mail: patrick.schenk@soziologie.unilu.ch 


\section{Karpik in the Bottle: Erklären Instanzen der Urteilsbildung den Kauf von Luxuswein?}

Zusammenfassung Bewertungsprozesse sind besonders komplex in Märkten für einzigartige Produkte. Man nehme den Kauf einer Flasche Luxuswein. Jeder Wein wurde in einer bestimmten Region, von einem bekannten Weinproduzenten und mit traditionellen Produktionsmethoden hergestellt. Wie können Konsumentinnen und Konsumenten solche einzigartigen Produkte miteinander vergleichen? Wie ist ein Markt für singuläre Produkte möglich? Lucien Karpiks „Ökonomie des Einzigartigen“ argumentiert, dass solche Märkte auf Instanzen der Urteilsbildung angewiesen sind, die Wissen zum Vergleich einzigartiger Produkte bereitstellen. Um den Erklärungsgehalt dieses Ansatzes zu testen, überprüft der Beitrag grundlegende Propositionen von Karpiks Theorie für die Nachfrage nach Luxuswein mittels quantitativer Methoden. Die Analyse kann die Theorie zu weiten Teilen bestätigen. Die Nachfrage nach Luxuswein korreliert mit der Verwendung der Instanzen der Urteilsbildung. Im Einklang mit der Theorie sind die Effekte der Instanzen der Urteilsbildung auf die Nachfrage nicht durch Informationsdefizite erklärbar. Es zeigen sich jedoch auch Abweichungen. Gewisse Instanzen der Urteilsbildung sind wichtiger für die Nachfrage als erwartet, währenddessen andere eine kleinere Rolle spielen. Zudem steht die Verwendung der Instanzen der Urteilsbildung mit Distinktionsprozessen in Verbindung, was in Karpiks Theorie vernachlässigt wird.

Schlüsselwörter Ökonomie des Einzigartigen · Valuation und Evaluation · Konsum · Unsicherheit · Distinktion

\section{On the Comparison of Unique Wines}

Sometimes, choosing a product is a straightforward task. Consider, for example, buying gasoline for a car. Gasoline is a highly standardized commodity. There is a one-dimensional quality scale based on the chemical composition of the liquid. Moreover, only a limited number of market contestants supply the product. Therefore, choosing the right product is comparatively easy. In other markets, product choice is much more complex and riddled with uncertainty. Think of buying a bottle of fine wine for the next dinner party. Every wine was produced in a specific vineyard with its particular soil and micro-climate, in a specific region with its particular tradition, by a specific wine producer using a particular production technique, and so on. The combination of all these particularities makes every wine unique, or so the sommeliers, wine journalists, and sophisticated wine aficionados say. But, how can unique wines be compared? How can consumers know what the "best" wine is? How do consumers deal with the uncertainty surrounding the quality of fine wine? How can consumers choose between unique products?

In recent decades, widespread agreement has emerged in economic sociology and economics that markets cannot be stable if uncertainty about product quality prevails (Beckert 2007). Practices of evaluation and valuation have therefore received increasing attention for explaining market outcomes. Practices of evaluation denote 
the ways in which actors assess the value of a product whereas practices of valuation refer to activities giving worth to goods and services (Lamont 2012; Bessy and Chauvin 2013). The former refers to quality judgments based on a certain combination of criteria (Aspers 2018), whereas the latter refers to the collective process of value creation in cultural fields (Bourdieu 2000). Empirically, however, evaluation and valuation are often strongly intertwined and mutually dependent. As one might easily imagine, evaluation and valuation are especially complex in markets in which goods and services are considered to be unique (Heintz 2016; Reckwitz 2020). Comparing gasoline might be easy, but what about movies, music, scientific papers, or wine? What exactly makes these objects unique? How can they be evaluated as better or worse on a graduated scale, not to mention assigning economic value in terms of price?

To analyze this problem, the French sociologist Lucien Karpik presented a comprehensive theory for the evaluation and valuation of singular products, fittingly called the "the economics of singularities" (Karpik 2010). According to Lucien Karpik, markets for singular products necessarily rely on social actors and artifacts providing knowledge to market participants on how to compare unique products. Karpik calls such social actors and artifacts judgment devices. For example, when the well-known wine critic Robert Parker assesses wine in terms of style, grapes, and regions, and thus considers sweet Riesling from Germany one of his favorites, the consumer might refer to this specific combination of criteria when choosing wine for herself. Judgment devices hence reduce the opacity of the market by giving reasons for product choice. They help to overcome the radical uncertainty involved in comparing singular products (Aspers and Beckert 2011). Further examples of judgment devices are guidebooks (e.g., the Gault Millau wine guide), regional denominations (e.g., Bordeaux), or personal networks (e.g., your friend who likes to talk about wine too much). All of these convey knowledge of product qualities. Without judgment devices, radical uncertainty would result in market failure. For Karpik, social processes of qualification are therefore at the heart of markets for singular products.

Karpik's approach has been called a fundamental contribution to economic sociology (Kraemer 2017), has received quite some attention in theoretical discussions (Hutter 2011; Healy 2011; Aspers 2018; Schenk 2012), and has inspired a host of empirical studies, the vast majority of which employ a qualitative methodology (Rodet 2012; Lefèvre 2015; Eloire 2010; Jourdain 2010; Felouzis and Perroton 2007; for an exception, see Franssen and Velthuis 2016). Although these studies provide important insights concerning the role of judgment devices in particular markets, systematic empirical analyses operationalizing Karpik's theory and testing fundamental hypotheses are still lacking. Hence, the theory's contribution to the explanation of pivotal market outcomes, such as price and demand, remains open for debate (Kraemer 2017).

The present paper seeks to make a step forward by testing fundamental propositions of the economics of singularities. To do so, I critically assess the explanatory contribution of Karpik's approach to the demand of fine wine in a quantitative setting. Fine wine is a prime example of a singular product, and is analyzed extensively by Karpik throughout his work. Fine wines are characterized by a particular 
combination of symbolic and material attributes, such as regional denominations, production methods, or producer names, creating an aura of uniqueness and exhibiting a high degree of uncertainty (Beverland 2006; Bruwer et al. 2013; Fourcade 2012). The focus on the demand side stems from the fact that the interrelations among product, consumers, and judgment devices are of primary concern for the economics of singularities. After all, consumers are the ones using judgment devices in order to overcome radical uncertainty and make product choices. Accordingly, Karpik (2010) devoted the vast majority of his theoretical analysis to the consumer side.

More precisely, the paper answers three related research questions, each tapping into crucial and contested parts of Karpik's arguments, discussed in detail below (Kraemer 2017; Schenk 2012; Healy 2011): (i) Does the use of judgment devices correlate with the demand for fine wine? (ii) Is the correlation between the use of judgment devices and the demand for fine wine explainable by information deficits? (iii) Are the demand for fine wine and the use of judgment devices related to processes of social distinction? In contrast to previous studies on judgment devices in the wine market (Beckert et al. 2016; Carter 2017; Frick and Simmons 2013; Zhao 2008; Fourcade 2012; Smith Maguire 2010), the paper comprehensively operationalizes all types of judgment devices proposed by Karpik, including personal networks, thereby providing new insights into the sociological explanation of wine demand. Furthermore, by shedding light on the interrelations among the engagement with judgment devices, uncertainty, and social distinction, the paper contributes to ongoing discussions in economic sociology on evaluation processes (Aspers 2018; Bessy and Chauvin 2013) and in cultural sociology on social distinction by the "what" and the "how" of consumption (Bourdieu 2007; Holt 1997). In the following, I begin with the presentation of the economics of singularities. The data, method, and measurements are outlined in the second section, before the third section presents and discusses the results. The final section draws conclusions, gives directions for future research, and outlines the mutual benefits of combining the economics of singularities with theories in cultural sociology.

\section{Fundamental Propositions of the Economics of Singularities}

\subsection{Singular Products, Judgment Devices, and the Authenticity Regime}

The economics of singularities is not a theory about any market - it is a theory about markets for singular products. According to Lucien Karpik, singular goods and services represent a particular class of products that has been overlooked in economic theory (Karpik 2011; Eloire 2010; Hutter 2011). Singular products are unique owing to their structured multidimensionality. They are defined by a particular combination of attributes and their interrelations. For instance, according to the economics of singularities, "Castillo Ygay" was not judged to be the "best" wine of 2020 (at least this is what Wine Spectator tells us) because it is the sum of some "Marqués de Murrieta," some Tempranillo, some Rioja, some red, and some 2010, but because of the very specific combination of these attributes (or maybe some others). Owing 
to this specific constellation of attributes Castillo Ygay is deemed to be unique. The contrast with the standard model of supply and demand in economic theory, in which goods and services are assumed to be homogenous and substitutable, is striking (Lancaster 1966).

Their uniqueness makes singular products incommensurable; they do not easily lend themselves to comparisons (Heintz 2016). Moreover, in markets for singular products, quality competition prevails over price competition (Karpik 2010). Singular products are therefore not primarily compared by price either. Yet without comparison, choice is not possible, and no market for singular products could exist. How is this resolved? It is only by highlighting some attributes and neglecting others, Karpik argues, that singular products can be commensurated. In theory, any combination of attributes could be used to compare singular products. Therefore, following Karpik, markets for singular products necessarily rely on judgments about product quality. Consumers need to actively and reflexively establish an appropriate combination of attributes constituting quality. Again, this is fundamentally different from the standard model of supply and demand, in which comparisons follow naturally from an objectively given quality standard, relative prices, or both (Aspers 2018). In the economics of singularities, actors need to establish a certain point of view by making judgments before they can make choices, enabling them to compare otherwise incommensurable products.

Yet each point of view is always contestable. Indeed, this multiplicity of points of views is constitutive for a market of singular products (Karpik 2013). If this were not the case, de-singularization would become rampant, and the market for singular products would not be a market for singular products anymore. The co-existence of various points of views implies that commensuration is just temporary and quality always underdetermined. One might judge a singular product from a certain perspective, but in principle some other perspective is legitimate, too. Consequently, markets for singular products are riddled with uncertainty. Are the 200 dollars for the bottle of Castillo Ygai really justified and if so, for what reasons? This renders markets for singular products opaque.

To dissipate opacity and to make judgments, consumers need help, which is provided by judgment devices. These are cognitive devices in the form of social actors or social artifacts (Aspers and Beckert 2011). They offer formatted and credible knowledge on the quality of singular products. Knowledge contains implicit and explicit evaluations, providing reasons for choosing a product. By providing evaluations, i.e., assessing the quality of a product on the basis of a certain point of view, judgment devices are simultaneously involved in the valuation of singular products, i.e., defining their quality on the basis of a certain point of view (Lamont 2012; Bessy and Chauvin 2013). This understanding of judgment devices is familiar to theorists in cultural sociology depicting the production of the value of cultural products as a collective process, involving a host of social actors, such as critics (Bourdieu 2000; Johnston and Baumann 2007), promoters (Smith Maguire 2010), or the mass media (Rössel et al. 2016). However, whereas cultural sociologists generally underscore the power of cultural intermediaries to bestow products with legitimacy and distinctive value, turning them into a symbolic resource for class struggles (Fourcade 2012; Zhao 2008; Lamont and Lareau 1988), the economics of singularities stresses 
the essential role of credible judgment devices to make a market for singular goods and services possible in the first place. Without judgment devices, consumers could not overcome the opacity of the market, resulting in market failure (Karpik 2013). Judgment devices are essential to counter radical uncertainty and to make product choices. They are therefore at the very heart of a functioning market for singular products.

Karpik differentiates five types of judgment devices: cicerones, rankings, appellations, confluences, and personal networks.

Cicerones denote critics and guidebooks providing evaluations of singular goods and services (Eloire 2010). The famous wine critic Robert Parker makes a formidable example. Parker talks about the tradition of a wine region, the wine producer's personality, and gives a detailed account of the flavors of a fine wine. Cicerones thus provide substantive knowledge without establishing a single order of worth.

This stands in stark contrast to rankings, which order singular products along an ordinal scale (Karpik 2011). Instead of substantive knowledge, rankings provide formal knowledge on the relative position of products within a single hierarchy. Parker Points are an example. In the Parker Wine Guide, wines are rated on a scale from 50 to 100 . Wines with 96-100 points are judged to be extraordinary, 90-95 as outstanding, and so on. Hence, the complexity of the quality of singular products is condensed into a one-dimensional scale-incommensurability is temporarily eliminated.

Appellations are names symbolizing the meanings that define singular products (Rodet 2012; Fourcade 2012). In the wine market, this can be the name of the wine producer, the winery, a wine region, or a label, such as the "Appelations d'Origine Contrôlée" in France.

Confluences channel consumers. They entail spatial arrangements of products in retail outlets or selling techniques (Jourdain 2010). In the wine market, consumers participate in wine tastings or in tours of wine estates, complete with the customary visit to the farm shop, of course.

Finally, there are personal networks. They encompass strong and weak ties, such as family members, friends, colleagues, or contacts (Lefèvre 2015; Felouzis and Perroton 2007). This type of judgment device "operate[s] by the circulation of the spoken word" (Karpik 2010, p. 45). It is hence not just about the actor's structural position in a network (Granovetter 1985) or social imitation and socialization (Bourdieu 2007; Beckert et al. 2016) but about using interpersonal relations in a particular way, namely to acquire knowledge on the quality of products by "word-of-mouth" (Hutter 2011).

Karpik's typology represents an outstanding contribution to the sociology of valuation and evaluation. It assembles and systematizes different types of judgment devices, treated separately in various disciplines, most notably economics (Frick and Simmons 2013; Akerlof 1970), economic sociology (Beckert et al. 2016; Granovetter 1985), and cultural sociology (Smith Maguire 2010; Fourcade 2012; Bourdieu 2000), in a theoretically grounded framework (Healy 2011; Aspers 2018). Karpik understands his typology as a tool for empirical research, and considers it to be sufficiently exhaustive for the analysis and explanation of the functioning of markets for singularities (Karpik 2013). A major task for the analysis of a concrete market, 
then, is the assessment of the relative importance of these devices for (e)valuation processes and for market outcomes, such as price and demand (Kraemer 2017).

Ultimately, the relative importance of a judgment device is an empirical question. Yet, in the fashion of Weberian ideal types, Karpik (2010) also characterized empirically observable markets as regimes of economic coordination. Accordingly, the market for fine wine is built upon impersonal, substantial, and critical devices. Karpik speaks of an "authenticity regime." These devices respect the originality and authenticity of the product and empower consumers to make autonomous judgments. Consequently, the market for fine wine rests on cicerones and appellations (Karpik 2013). Rankings and confluences should play a subordinate role, as they represent formal and commercial devices that de-singularize products by ordering them on a one-dimensional scale and by channeling consumers to increase profits respectively. Personal networks should play a lesser role, too, as they are primarily relevant in markets without other credible judgment devices (Bessy and Chauvin 2013).

In sum, according to the economics of singularities, judgment devices are inextricably connected to the demand for fine wine. Using judgment devices is necessary for consumers to overcome their cognitive deficit, to qualify the product from a certain point of view, and to make product choices. According to Karpik's ideal-typical model of the authenticity regime, cicerones and appellations are most important in the market for fine wine. Conversely, if consumers do not use judgment devices, they do not have the knowledge to make a reasonable judgment and will therefore refrain from purchasing the product. ${ }^{1}$ Three fundamental hypotheses can be derived from Karpik's theory:

H1 The use of judgment devices correlates positively with the demand for fine wine.

H2 The uses of cicerones (H2a) and appellations (H2b) are of primary importance to the demand for fine wine.

H3 The uses of rankings (H3a), confluences (H3b), and personal networks (H3c) are of secondary importance to the demand for fine wine.

\subsection{Information and Interpretation}

The economics of singularities is not the only theory addressing uncertainty and risk in markets, of course. Information economics has been devoted to this problem too. Indeed, Karpik developed his theory not only in contrast to the standard model of

\footnotetext{
1 Once consumers have sufficient knowledge, they use their means (money, time, etc.) efficiently to buy a singular product of high quality. Yet Karpik maintains that new knowledge may lead to a re-qualification of singular products, changing the consumers' goals. The act of buying a singular product therefore needs to be understood as a dynamic process, combining a symbolic (qualification) and an economic logic (efficiency). Evidently, Karpik's analytical focus is on the former.
} 
supply and demand but also as an explicit alternative to the more recent strand of information economics, arguing that the economics of singularities provides a more accurate explanation for the demand of singular products. It has been criticized, however, that it remains unclear whether the economics of singularities actually provides a better explanation, on a theoretical as well as on an empirical level (Schenk 2012). How do the two theories differ, then?

According to information economics, in the vast majority of markets, consumers have to make decisions based on incomplete information. This makes product choice a risky endeavor. In the wine market, information imperfections stem from the product's search or experience attributes. Search attributes concern informational deficiencies related to product search. Normally, consumers are not familiar with all possible product alternatives and their prices. There is a risk of not being aware of the best alternative (Stigler 1961). Everyone who has been overwhelmed by the variety of wines in the supermarket shelf has encountered this problem. Experience attributes refer to information deficiencies that are only solvable after buying and actually consuming the product (Akerlof 1970). Think of the taste of a fine wine. It is only after purchasing it that consumers are allowed to open the bottle and actually drink it, thereby experiencing its taste.

Consumers reduce risk before they buy wine (Bruwer et al. 2013). They do so by acquiring information through a variety of sources. They might engage with wine sellers who provide information on product alternatives, thereby reducing risk owing to search attributes (Bessy and Chauvin 2013). Wine tastings offer product sampling, reducing the risk based on experience attributes (Schneider 1997). Finally, reputation is considered as a signal for wine quality in information economics, be it in the form of individual (the producer's name) or collective reputation (regions or labels) (Frick and Simmons 2013).

This whole story sounds very similar to the economics of singularities. However, if we follow Karpik, there is a crucial difference. In contrast to information sources, judgment devices do not simply solve an information problem. They provide knowledge to overcome an interpretation problem, i.e., what constitutes the quality of a singular product in the first place (Kraemer 2017).

Interpretation can be analytically separated into two processes. First, consumers need to frame the product in a certain way. They need to categorize and understand the meaning of a singular product. Judgment devices play an important part in categorization processes and the creation of the symbolic content of singular products (Aspers and Beckert 2011). Critics talk about the traditions of a certain region, thereby lumping wines into a category and connecting the product to meanings of historicity and authenticity, for example (Beverland 2006). Second, consumers need to establish the relevant composition of evaluation criteria and their relative weights in order to compare singular products (Bessy and Chauvin 2013; Heintz 2016). How to compare two bottles of wine? Taste? Color? Production methods? Bottle shape? In markets for singularities, uncertainty does not simply concern missing information about product characteristics (whether the wine has a dry taste), but the very definition of the relevant criteria for judging the quality of an otherwise incommensurable product, that is, how a combination of certain attributes constitutes quality (why the dryness of the wine and not the shape of the bottle matters for quality). Hence, 
interpretation does not just involve the cognitive processing of external stimuli. Even if a consumer had gathered all the sensory information about a singular product, she would still not understand why it is highly valued on the basis of this information alone (Rössel 2007). Very much in line with theories in cultural sociology (Bourdieu 2000; Smith Maguire 2010; Fourcade 2012), this is because the value of a singular product is a social construct. No amount of information on the product solves quality uncertainty, as uncertainty revolves around the social consensus regarding the very notion of quality itself.

Two historical examples illustrate this point. First, over the course of the twentieth century, criteria of aesthetics and authenticity, such as unique taste, the producer's name, the wine region, tradition, or artisanal production techniques, have become more prevalent in media reports on wine, increasing their significance in quality evaluations (Rössel et al. 2016). Second, and more recently, the status of rosé wine has experienced a dramatic transformation. Traditionally considered inferior to other types of wine, critics started to reclassify rosé by highlighting attributes such as "dry style" and the "old world" for quality evaluations, making them comparable with valorized wine categories (Fitzmaurice 2017). In both cases, judgment devices did not play a passive role as information providers. They produced knowledge on the relevant evaluation criteria and the meaning of wine, which (co-)constituted the very notion of a quality wine itself. Even with perfect information on color, region, production methods, and so on, quality judgments would have vastly differed at different points in time. The radical uncertainty in markets for singular products is hence not a problem of missing information, as theorized in information economics. It is due to the socially contingent definition of the product's quality (Rössel 2007).

In short, according to Karpik, making a judgment is not the passive processing of information, reflecting some pre-given reality, but an activity that synthesizes facts and values. Correspondingly, judgment devices reduce the opacity of the market by providing knowledge on the meaning of singular products and the composition of relevant evaluation criteria. Therefore, the function of judgment devices cannot be explained by the reduction of information deficits alone. In contrast to information economics, then, the economics of singularities shifts the focus from choice to judgment, from information sources to judgment devices, from risk to radical uncertainty. Although both theories address similar artifacts, actors, and institutions, their functioning is explained differently. To simplify the presentation, I speak of judgment devices in both instances. Two competing hypotheses, one in favor of information economics (H4a) and one in favor of the economics of singularities (H4b), follow:

$\mathrm{H} 4 \mathrm{a}$ The effects of judgment devices on the demand for fine wine are mediated by the reduction of perceived risks in terms of search and experience attributes.

$H 4 b$ The effects of judgment devices on the demand for fine wine are not mediated by the reduction of perceived risks in terms of search and experience attributes. 


\subsection{Autonomy, Voluntary Dependence, and Social Distinction}

For the economics of singularities, neither product choice nor the choice of judgment devices is coerced. Quite the contrary. In markets for singular products, consumers are free to follow their own personal preferences (Karpik 2013). The relation between a judgment device and the consumer is one of voluntary dependence and trust, not one of obedience and prescription (Karpik 2010). What is surprisingly missing from this picture is normative expectations or external rewards by other social actors for consuming singular products or making appropriate judgments (Kraemer 2017). For Karpik, the individual consumer is intrinsically motivated to use judgment devices in order to overcome radical uncertainty. This stands in stark contrast to accounts in cultural sociology.

As Pierre Bourdieu (2007) famously argued, consumption is always bound up with processes of social distinction. Owing to their socially conditioned dispositions, high-status consumers have a taste for culturally legitimate consumption practices. Such practices serve as status signals used for social and cultural exclusion (Lamont and Lareau 1988). They are validated by members of a social group (Smith Maguire 2010), leading to social approval and disapproval (Rössel and Hoelscher 2017). And they have classificatory effects, consciously or unconsciously, creating and maintaining symbolic boundaries (Lamont 2012). Consumers with the right set of dispositions possess an incorporated sense for the logic of the game (Bourdieu and Wacquant 1996). They do not consciously and deliberately partake in high-status practices with the goal of gaining prestige. Rather, culturally competent consumers have a practical understanding of what is normatively expected and socially valid in a situation (Strand and Lizardo 2015), or, conversely, do not even think of the courses of actions that are inappropriate in a social context (Bourdieu 2007) —whether it is a good idea to bring boxed wine to their boss's dinner party or not, for example (it normally is not). Thus, dispositions generate practices that are objectively linked to social distinction, without necessarily being the product of a conscious and rational strategy (Bourdieu and Wacquant 1996).

Crucially, these practices not only concern what people buy (i.e., an expensive bottle of wine) but also how they consume cultural goods and services, including the use of judgment devices. Indeed, as previous research on classification, cultural intermediaries, and social status suggests, judgment devices should be intricately linked to processes of social distinction. First, judgment devices also function as "status anchoring devices" (Fourcade 2012, p. 527), enabling the categorization and social hierarchization of products, producers, and consumers (Zhao 2008; Bourdieu 2000; Johnston and Baumann 2007). Second, judgment devices are themselves part of the legitimate ways to appropriate fine wine. As Smith Maguire (2017, p. 48) found in an analysis of media discourse, the use of judgment devices is framed as a way to turn "wine drinking from a hedonistic experience of intoxication to an exercise of reason, self-restraint and formal rules of assessment." Judgment devices are part of a cultivated, distanced, reflexive, and intellectualized practice of wine consumption (Howland 2013; Bourdieu 2007). Under conditions of cultural omnivorousness and democratization (Johnston and Baumann 2007), the legitimate 
appropriation of fine wine might even be more consequential for distinction than simply drinking an expensive cuvée.

In sum, for cultural sociologists, the "what" and the "how" of consumption are essentially linked to processes of social distinction. In contrast, these processes are absent in the economics of singularities (Kraemer 2017). By stressing personal preferences, autonomy, and voluntary dependence, Karpik neglects normative expectations and the consequences of consuming singular products for social approval and prestige. By focusing on the function of judgment devices to counter radical uncertainty, he ignores the social function of judgment devices to maintain symbolic boundaries (Lamont 2012). Two connected hypotheses, criticizing Karpik's notion of autonomy and voluntary dependence, follow:

H5 Social distinction correlates positively with the demand for fine wine (H5a) and the use of judgment devices (H5b).

\section{Data, Measurement, Method}

The economics of singularities puts forward fundamental propositions on the interrelations among singular products, judgment devices, and consumers. To empirically test these propositions, I conducted a quantitative analysis with data from a standardized mail survey on wine consumption, collected in four German cities (Mainz, Wiesbaden, Hamburg, Cologne) in 2009. These cities were primarily chosen to take regional variation in wine consumption patterns into account. Mainz and Wiesbaden represent smaller cities situated in wine-producing regions, whereas Hamburg and Cologne represent two large cities outside of wine-producing areas. The population includes all residents aged 18 years or older with German citizenship. To potentially falsify the hypotheses, the respondents need to be sufficiently heterogenous and encompass wine consumers and nonconsumers as well as users and non-users of judgment devices. A sample of the general population (covering respondents from wine-producing and non-producing regions) fully meets this requirement. Moreover, including wine consumers from various price segments allows for a more rigorous test of $\mathrm{H} 2$ and $\mathrm{H} 3$, stating that certain judgment devices are of special importance in the case of fine wine. In total, 4000 individuals were randomly selected from the population registers. Overall, the adjusted response rate is $27 \%$, taking neutral sampling failures into account.

The data allow the comprehensive operationalization of Karpik's typology (descriptive statistics of the variables for the analysis can be found in the online appendix in table OA1). Cicerones are operationalized with three items measuring the frequencies with which a respondent reads articles on wine in the press, consults wine critics, or watches wine reports on TV. All these instances provide substantive knowledge on wine. Confluences are operationalized by two items measuring the frequencies of attending wine seminars or wine tours. Personal networks are measured by two items, asking respondents how often they acquire information on wine from friends and acquaintances or family members and relatives. Each of these items encompasses five categories ranging from "never" to "very often." Appella- 
tions are operationalized by three items, measuring the extent to which respondents take note of the wine producer, the region, or the vineyard when obtaining information. Likewise, rankings are measured by the extent to which respondents consider prizes or competitions on the one hand and quality seals on the other. The items include five categories ranging from "does not apply at all" to "applies completely." Internal reliability for all five judgment devices is acceptable with a Cronbach's alpha of 0.68 for confluences to very good with alpha 0.8 for appellations. Additionally, a confirmatory factor analysis of Karpik's typology yields a very good overall fit $\left(\chi^{2}=113.2 ; \mathrm{df}=44 ; \mathrm{CFI}=0.98\right.$; TLI $=0.96$; $\mathrm{RMSEA}=0.045 ; 95 \% \mathrm{CI}$ for $\mathrm{RMSEA}=[0.035 ; 0.056] ; \mathrm{SRMR}=0.032 ; n=769)$. All factor loadings are above 0.6 and all constructs exhibit convergent and discriminant validity according to the Fornell-Larcker criterion (Fornell and Larcker 1981). That is, the average variance extracted for each latent variable is larger than the squared correlations between the latent variables (detailed results are available on request). This is strong empirical evidence for the conceptual validity of Karpik's typology.

In line with research on subjective risk perception (Schneider 1997), risks were measured by asking respondents about information deficits directly. To operationalize risk in terms of search attributes, respondents rated the extent to which they face information deficits in terms of the availability of wine: "Faced with the vast options on the wine shelf, I do not know which wine to buy." Risk due to experience attributes refers to information deficits in terms of wine taste: "When purchasing a bottle of wine, one never knows exactly what the wine is going to taste like in reality." Both items include five categories ranging from "does not apply at all" to "applies entirely".

Social distinction refers to the consequences of consumption for social validation and the creation of symbolic boundaries. As Bourdieu (2007) points out, on the level of social practice, distinction rests on the ways in which actors categorize themselves and others based on their taste. According to Holt (1997, p. 96), this manifests in a preference "for colleagues, friends, and acquaintances who share their tastes." I thus use two indicators to measure the extent to which wine consumption is understood to be bound up in processes of social distinction. The first is termed "social function": "I drink wine to share something special with others" (cf. Verboord 2010). This relates to the consequences of wine consumption for social approval based on the respondent's own tastes. The second is termed "normative expectation": "I expect my friends to be interested in wine" (cf. Rössel and Hoelscher 2017). It refers to the tastes of others and relates to group-specific consumption norms. High values on these indicators reflect a practical understanding of wine consumption as a cultural signal used for social inclusion/exclusion and the creation of symbolic boundaries (Lamont and Lareau 1988; Bourdieu and Wacquant 1996). These items correlate only moderately $(r=0.17)$. As they are both vital aspects of social distinction, they are included separately in the analysis.

Finally, the demand for fine wine is operationalized by the maximum price a respondent pays for a bottle of wine, measured on a seven-point scale, with categories ranging from "less than 3 Euros" to "more than 50 Euros". Because fine wines are in general more expensive (Beckert et al. 2016), the maximum amount a consumer has spent on wine is a good indicator of the purchase of fine wine. It is preferable 
to the self-reported frequency of buying fine wine, as understandings of what "fine wine" actually means may vary systematically between respondents. Yet, another definitional issue arises: How much does a wine have to cost in order to count as a "fine wine"? Any threshold is necessarily arbitrary. By using quantile regressions for the analysis of the demand for fine wine, I can (largely) sidestep these definitional quarrels.

To understand what quantile regression does, it is easiest to compare it with the well-known OLS regression technique (Cameron and Trivedi 2010). OLS regression predicts the average of an outcome variable $\mathrm{Y}$, conditional on a set of covariates $\mathrm{X}$. Furthermore, in OLS regression, it is assumed that the relationships between the outcome variable and the covariates are constant across the distribution of Y. These characteristics are ill-suited for the present analysis. First, one might argue that fine wines are those wines at the top of the price distribution, for example, the most expensive $25 \%$. Parameters other than the conditional mean would then be of interest. Second, from the perspective of the economics of singularities, cicerones and appellations should be especially relevant for fine wine but not necessarily for standardized wine, commanding lower prices. Hence, the relationship between judgment devices and the maximum price paid for wine is not assumed to be constant across price segments.

In contrast, quantile regressions allow me to estimate the covariates of the maximum price paid for a bottle of wine at different points in the distribution of the maximum amount paid per bottle of wine, each regression producing different estimators. I thereby arrive at a more complete picture of the relationships between judgment devices, risk perception, and social distinction on the one hand and wine demand on the other, while at the same time avoiding an arbitrary definition of "fine wine" by a specific bottle price. Separate quantile regressions were computed for every decile of the dependent variable (10th, 20th, ..., 90th percentile). I then combined the results and plotted the standardized regression coefficients, together with their $95 \%$ confidence intervals, against the quantiles of the maximum price paid per bottle.

All models comprise several control variables: gender, age, the respondent's city of residence, net household equivalence income, and years of schooling. Additionally, I added three variables measuring a highbrow, middlebrow, and lowbrow lifestyle on the basis of cultural preferences and participation (all Cronbach's alphas above 0.71 ). Including lifestyles makes it possible to separate the specific statistical effects of judgment devices, risk perception, and social distinction from the effects of the social milieu, representing potential confounding factors giving rise to spurious correlations. Last, missing values are handled using multiple imputation (Enders 2010). Twenty imputations were generated. All variables previously described were included in the imputation process, as well as a set of auxiliary variables. An inspection of the distributions of the variables in each imputed dataset allowed an assessment of the validity of the procedure. No anomalies were detected. After multiple imputation, 919 cases are available for the regression analysis. 


\section{The Use of Judgment Devices in the Market for Fine Wine: Empirical Results}

The first series of quantile regressions estimates the effects of the use of the five types of judgment devices on wine demand (i.e., the maximum amount paid for a bottle of wine). At the median, which corresponds to prices from 10 to 15 Euros, all judgment devices show positive and significant correlations with wine demand (Fig. 1, variables labeled with "M1"). This is evidence for the first hypothesis.
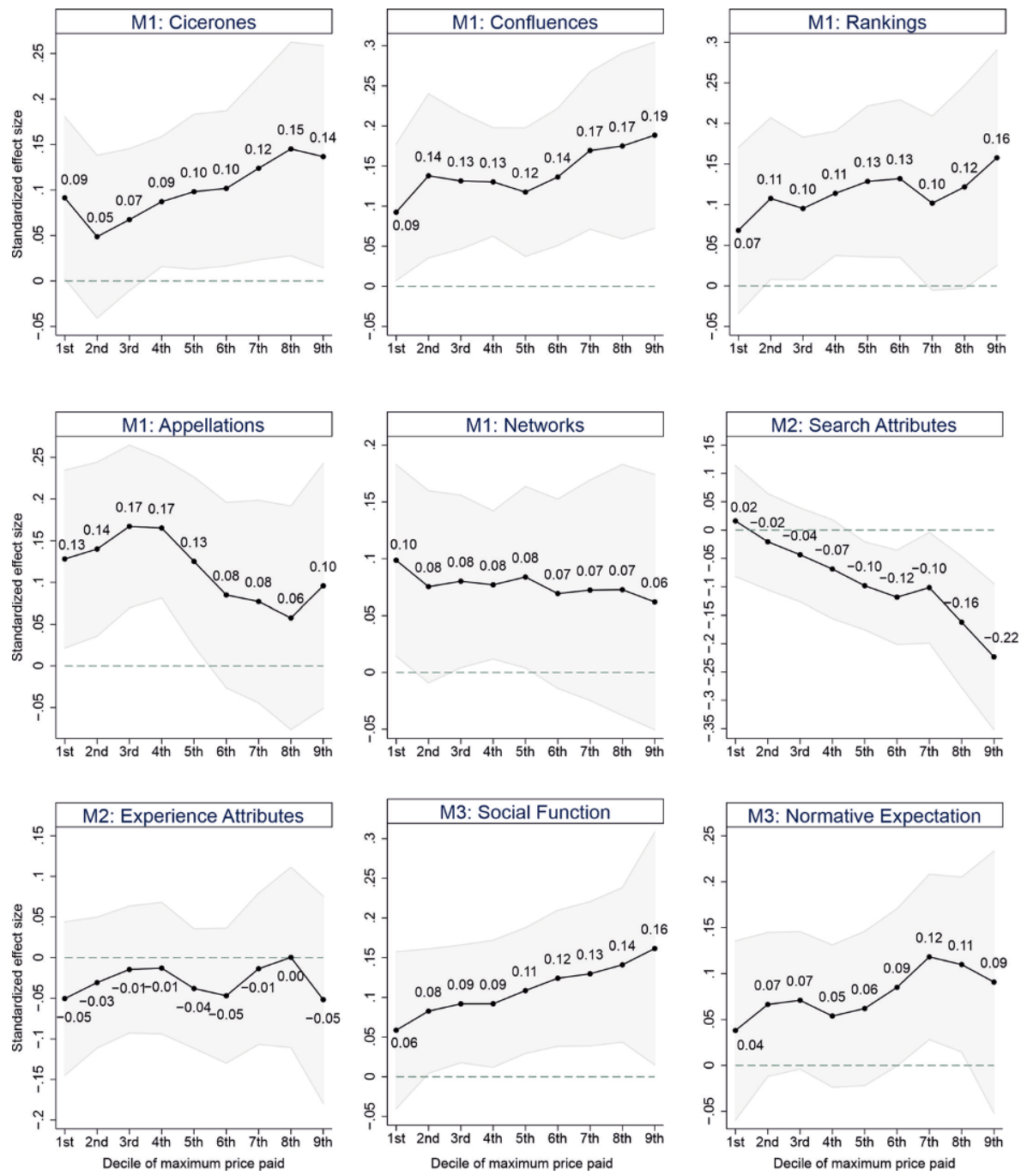

Fig. 1 Quantile regressions of the maximum price paid for wine (i.e., demand for fine wine). Standardized regression coefficients with 95\% confidence intervals. Model 1 (M1): judgment devices, Model 2 (M2): information deficits, Model 3 (M3): social distinction. Control variables not shown. The number of cases for all models is 919 
However, a closer look reveals that the strength of the correlations varies between the quantiles of the maximum price paid.

In the case of cicerones, the size of the standardized regression coefficients increases over the distribution of the maximum amount paid per bottle (Fig. 1, M1: Cicerones). At the 2 nd decile, the effect is weak, with $\beta=0.05$. After the 3 rd decile, it becomes significant (on the 5\% level). At the 8 th decile the variable has a substantial effect on wine demand, with $\beta=0.15$. The use of cicerones is hence most relevant for the demand for fine wine. Yet, compared with the effects of the remaining judgment devices, the correlation is not especially strong. Hypothesis $2 \mathrm{a}$ is thus not supported by the data. Confluences are significantly correlated with the maximum price paid for wine at every decile of the distribution. The correlation becomes especially strong after the median, reaching a size of $\beta=0.19$ at the 9 th decile (Fig. 1, M1: Confluences). This is unexpected from the perspective of the economics of singularities. Confluences should play a smaller role in the authenticity regime. Likewise, rankings correlate significantly with wine demand over the majority of the distribution of the dependent variable (Fig. 1, M1: Rankings), again running counter to theoretical expectations. At the lower and intermediate deciles (2nd to 6th decile), we find moderate but significant correlations, with $\beta=0.12$, on average. At the 9th decile, the correlation becomes rather substantial, with $\beta=0.16$. Appellations are most strongly related to wine demand in the lower price segments, contradicting the theoretical expectations too (Fig. 1, M1: Appellations). The partial correlation is strongest at the 3rd decile, with $\beta=0.17$. The effect becomes weaker thereafter and is insignificant from the 6th decile onward. Hence, the hypotheses on the relative importance of confluences, rankings, and appellations in the authenticity regime (H2b, H3a, H3b) cannot be confirmed. Finally, the use of personal networks is just weakly correlated with wine demand, as predicted in H3c (Fig. 1, M1: Networks). They have significant effects at the lowest decile and at intermediate deciles (3rd, 4th, and 5th), but the effects sizes are all 0.1 or smaller.

Historical and institutional characteristics of the German wine market provide a tentative explanation for some of these unexpected findings (Carter 2017; Zhao 2008; Fourcade 2012). Germany has a long history of wine production and the demand for regional wines is still strong, especially in wine-producing regions (Pape 2012). This might explain the pervasive role of confluences (wine seminars and wine tours) as a judgment device. Furthermore, the German wine market is characterized by the coexistence of two ranking devices issued by two separate and competing institutions for quality assessments: the official German wine classification by the state and one by a private association of wine producers named the "Verband Deutscher Prädikatsweingüter" (VDP). According to previous studies, the former is more oriented toward the mass market, employing a standardized approach to assessing wine based on taste and chemical composition, whereas the latter is restricted to fine wine, promoting a holistic notion of quality akin to the French concept of "terroir" (Frick and Simmons 2013; Rössel and Beckert 2012; Schenk and Rössel 2012; Fourcade 2012). The use of these ranking-devices might therefore yield different effects at different points of the price distribution. To test this argument, I repeated the analysis and separated the two indicators for rankings. One indicator measures classification by the state, the other quality seals by the VDP. And indeed, the former correlates 
significantly and positively with demand in the lower deciles of the price distribution only, whereas the latter correlates significantly with the most expensive wines only (results not presented). Lumping these two subtypes of ranking devices together generates the U-shaped pattern observed in Model 1, indicating substantial correlations for lower and medium-price segments and for the highest price segments (even more pronounced in Model 4 in Fig. 2). In sum, the theoretically unexpected
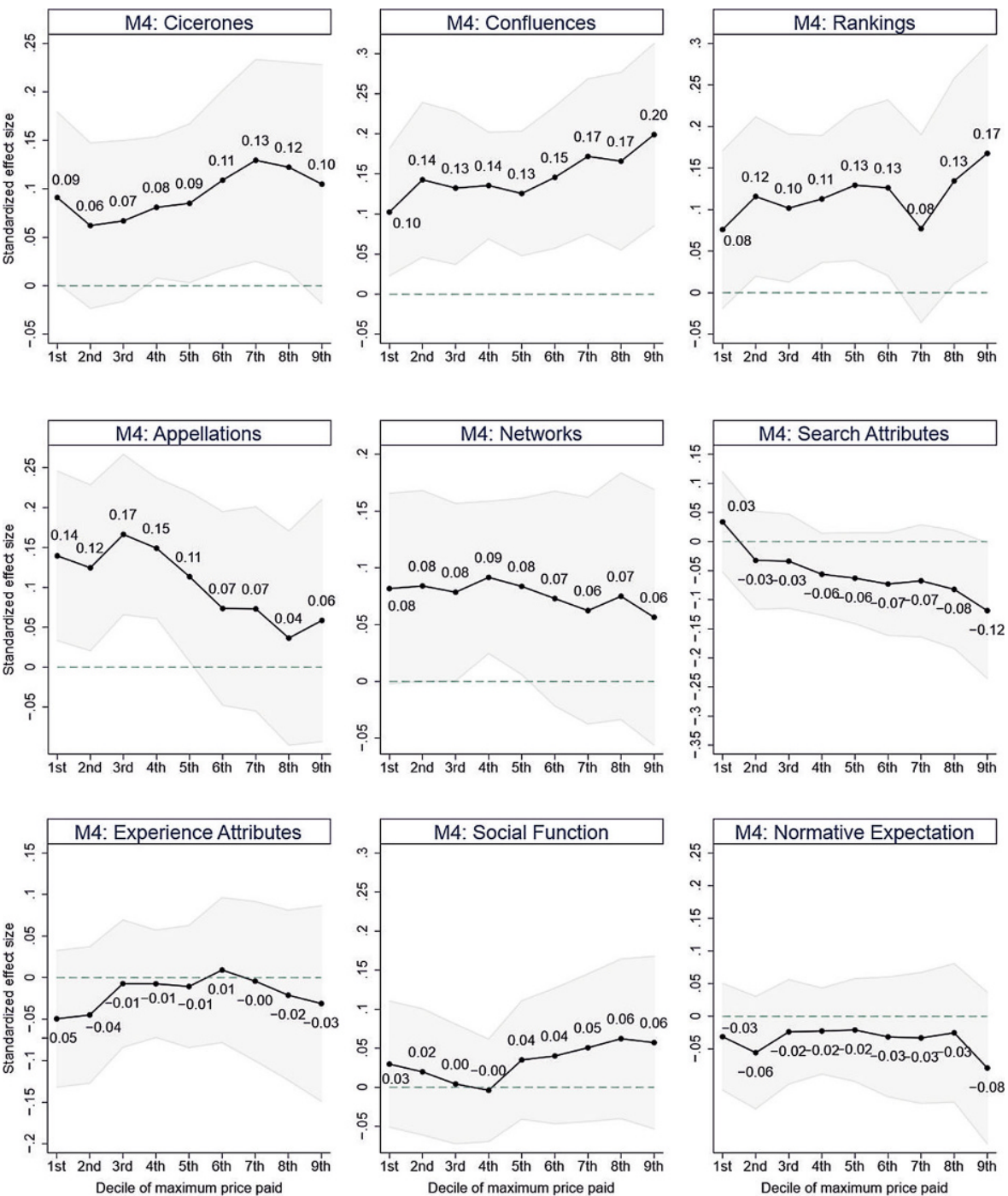

Fig. 2 Quantile regression of the maximum price paid for wine (i.e., demand for fine wine). Standardized regression coefficients with $95 \%$ confidence intervals. Model 4 (M4): combined model of judgment devices, information deficits, and social distinction. Control variables not shown. The number of cases is 919 
importance of confluences and rankings might reflect the particular landscape of the German wine field (Schenk and Rössel 2012; Rössel and Beckert 2012).

Although the separate effects of the types of judgment devices might not be particularly strong, the overall explanatory power of the theory is satisfactory. Especially in the intermediate and higher price segments, the Pseudo- $\mathrm{R}^{2}$ are considerable, with values ranging from 0.17 (4th decile) to 0.22 (9th decile). Hence, Karpik's theory makes a valuable contribution to the explanation of prices and demand (Kraemer 2017; Schenk 2012). Nevertheless, there is still much room for improving explanatory power, which casts doubt on Karpik's assertion that judgment devices are sufficient for explaining a market for singularities (Karpik 2013).

Model 2 estimates the relationships between wine demand and information deficits. Risk due to search attributes is a significant covariate of wine demand, but only for more expensive wines starting at the 5th decile (Fig. 1, M2: Search Attributes). This is a plausible finding. As the purchase of more expensive wines has higher opportunity costs (i.e., not finding the "right" bottle of wine), search costs should be more relevant for more expensive wines than for cheaper bottles (Stigler 1961). Risk due to experience attributes does not correlate significantly with wine demand at any price level (Fig. 1, M2: Experience Attributes). At first glance, this contradicts the finding in previous research that wine consumers perceive taste as a serious risk (Bruwer et al. 2013). However, given that the costs are not too high, consumers might still buy wine, despite perceiving substantial risk if the expected utility of the purchase is positive. This explanation is of course less likely to hold in higher price segments. With increasing costs, buying a bottle of fine wine with unknown experience attributes stops being worth the gamble. From the perspective of information economics, then, it is the absent correlations for higher priced wines that are especially puzzling. A possible explanation in this case refers to varietyseeking among consumers of fine wine. According to a study by Beverland (2006), consumers with more wine knowledge and higher spending on wine expect and even appreciate a limited amount of variation in taste. Consequently, these consumers might buy more expensive wine and perceive risk related to taste at the same time, even if the purchase involves substantial monetary costs.

Model 3 regresses the maximum amount paid for a bottle of wine on the variables measuring social distinction. The variable for the social function of wine consumption yields a significant effect on all deciles except the lowest (Fig. 1, M3: Social Function). The strength of the relationship increases with the maximum amount paid for a bottle of wine and becomes quite substantial, with $\beta=0.16$, at the end of the distribution. Similarly, the effect of normative expectation becomes stronger for more expensive wines, only being significant for the 7th and 8th deciles (Fig. 1, M3: Normative Expectation). Taken together, the results indicate that social distinction is linked to wine demand, as stipulated in hypothesis 5a, most strongly for more expensive fine wines (Verboord 2010; Rössel and Hoelscher 2017). ${ }^{2}$ This is a plausible finding from a theoretical perspective. Finer wines bear more potential for gener-

\footnotetext{
2 The effects of the normative expectation are statistically significant in the 3rd to the 6th deciles if the models do not control for lifestyles. The substantial conclusions from this alternative model specification remain the same, however. The effects of social distinction become stronger in the higher price segments.
} 
ating social prestige and accruing external rewards than standardized wines sold at lower prices. They are part of the "legitimate culture" and require more economic and cultural capital (Bourdieu 2007; Beckert et al. 2016). I will return to this below.

Model 4 combines all explanatory variables (Fig. 2). First of all, we find that the coefficients for the five types of judgment devices are rather robust. In contrast, the coefficients for the risk due to search attributes become insignificant in the combined model (Fig. 2, M4: Search Attributes). This is the opposite of what information economics predicts. For the most part, the effects of judgment devices are not mediated by perceived risks. One notable exception is cicerones, which show a (comparatively) substantial reduction of the effect size in the quantile regression for the 9th decile, rendering the coefficient insignificant (Fig. 2, M4: Cicerones). Still, by large, the functioning of judgment devices is not explainable by the reduction of information deficits alone (Schenk 2012). The finding is consistent with the reasoning of the economics of singularities. Accordingly, judgment devices provide more fundamental knowledge on the qualification of singular products, solving an interpretation and not just an information problem. H4a must therefore be rejected, whereas $\mathrm{H} 4 \mathrm{~b}$ in favor of the economics of singularities is consistent with the data.

Once the use of judgment devices is accounted for, the social function and the normative expectation of wine consumption become insignificant too (Fig. 2, M4: Social Function and M4: Normative Expectation). This is very much in line with Karpik's (2010) characterization of a reflexive and autonomous consumer, choosing singular products based on the knowledge provided by judgment devices and not because of social pressure, normative expectations, or social rewards (Howland 2013). However, the results so far hint at the possibility that processes of social distinction matter indirectly, not for the "what" but for the "how" of consumption.

I therefore computed a series of OLS regressions with the five types of judgment devices as dependent variables and the social function and the normative expectation as independent variables (Table 1). In these models, the social function as well as the normative expectation are both substantial, positive, and highly significant covariates of the use of all judgment devices. Keep in mind that these models control for income, education, and general lifestyles. The effects of social function and normative expectation are thus likely to reflect a practical sense of the social consequences of using judgment devices rather than some unspecified general cultural dispositions (Bourdieu and Wacquant 1996; Strand and Lizardo 2015). Hypothesis 5b is thus fully supported by the data.

Table 1 OLS regressions for the use of judgment devices. Standardized coefficients, standard errors in parentheses. Control variables not shown

\begin{tabular}{lccccc}
\hline & Cicerones & Appellations & Rankings & Confluences & Personal networks \\
\hline Social & $0.18^{* * *}$ & $0.17 * * *$ & $0.12^{* * *}$ & $0.11^{* *}$ & $0.16^{* * *}$ \\
function & $(0.017)$ & $(0.025)$ & $(0.028)$ & $(0.015)$ & $(0.025)$ \\
Normative & $0.24 * * *$ & $0.22^{* * *}$ & $0.20^{* * *}$ & $0.19^{* * *}$ & $0.11^{* *}$ \\
expectation & $(0.025)$ & $(0.037)$ & $(0.040)$ & $(0.022)$ & $(0.038)$ \\
\hline$n$ & 919 & 919 & 919 & 919 & 919 \\
\hline
\end{tabular}

$* p<0.05, * * p<0.01, * * * p<0.001$ 
This finding helps to explain why social distinction matters especially with respect to the demand for higher-priced wines, obtained in Model 3. It suggests that the distinctive value of consuming fine wine depends on cultural competences for their legitimate appropriation. This type of cultural capital is acquired through judgment devices (Howland 2013). The consumption of standardized wines, in contrast, does not require the same type of cultural capital and is hence less consequential for processes of social distinction. Interestingly, opposite to the demand for fine wine, normative expectation correlates even more strongly with the use of all judgment devices, except for personal networks, than the social function of wine consumption. The "how" of consumption is hence more thoroughly linked to consumption norms than the "what" (Lamont 2012). In general, judgment devices appear to be an integral part of processes of social distinction and the drawing of symbolic boundaries by fine wine consumption (Bourdieu 2007). They enable consumers to engage in highly legitimate, reflexive, and intellectualized ways of drinking fine wine (Smith Maguire 2017; Howland 2013). In so doing, judgment devices simultaneously hierarchize products, producers, and consumers (Fourcade 2012). These results strongly corroborate theories in cultural sociology on the intricate connections between classification, cultural intermediaries, and social status (Bourdieu 2000; Zhao 2008; Johnston and Baumann 2007; Fourcade 2012; Smith Maguire 2010).

\section{5 "Valuing the Unique": The Explanatory Contribution of the Economics of Singularities}

Capitalist societies are increasingly characterized by the production and consumption of goods and services deemed to be extraordinary, authentic, and unique (Reckwitz 2020; Heintz 2016). Lucien Karpik's economics of singularities represents a comprehensive account of (e)valuation processes in such markets for singular products (Karpik 2010, 2013; Aspers 2018). Yet it is still open for debate whether the theory holds up to its promises (Healy 2011; Kraemer 2017; Schenk 2012). Although certainly not the end of the story, the quantitative analysis of the demand for fine wine provides ample support for the economics of singularities-but also reveals weaknesses.

First, the use of different types of judgment devices correlates consistently and substantially with the demand for fine wine, resulting in considerable explanatory power. Karpik's theory hence makes a significant contribution to the explanation of prices and demand (Kraemer 2017; Schenk 2012). Yet the findings are mixed when it comes to Karpik's characterization of the market for fine wine as an authenticity regime (Healy 2011). In line with the theoretical expectations, cicerones correlate substantially with the demand for fine wine. Personal networks play a subordinate role. In contrast to the theoretical arguments, confluences co-vary strongly with the demand for fine wine too, whereas appellations are unrelated to the purchase of the most expensive wines. Rankings are relevant for lower priced wines but also for the wines at the very top of the price distribution.

Second, it is worth repeating that Karpik's typology of judgment devices showed a very good overall fit in a confirmatory factor analysis. While others have stressed 
the theoretical merits of Karpik's typology (Aspers and Beckert 2011; Aspers 2018), this finding adds to the discussion by providing statistical evidence for its empirical validity. One caveat for the analysis of the German wine market was, however, that the typology does not differentiate between sub-types of ranking devices. Hence, researchers are advised to fine-tune the typology to the institutional context of the market under investigation.

Third, the results suggest that the economics of singularities also takes insufficient account of the historical and institutional embeddedness when explaining the relative importance of judgment devices (Healy 2011). The thorough importance of confluences and the differentiated effects of ranking devices are likely to reflect the particular landscape of the German wine field. A focused case analysis of the German and the French market might be especially fruitful for deeper exploration of this explanation, not least because Karpik's analysis was predominantly based on the French wine market. As Fourcade (2012) concludes, appellations, related to notions of "terroir," play an especially prominent role in France, which might be reflected in Karpik's characterization of the wine market as an authenticity regime. In general, acknowledging the wider social embeddedness of markets opens up new opportunities to study the effects of judgment devices on the demand of singular products in a comparative manner across institutional, historical, and national contexts (Carter 2017; Zhao 2008; Aspers 2018; Fourcade 2012).

Fourth, according to the statistical results, the functioning of judgment devices cannot be explained by the reduction of information deficits alone. This is in line with Karpik's argument that judgment devices solve a more fundamental interpretation problem, i.e., what constitutes the quality of a singular product (Kraemer 2017; Aspers and Beckert 2011; Heintz 2016). They provide not only information on some pregiven reality (e.g., the regional origin) but also knowledge on the symbolic content of singular products and the composition of relevant evaluation criteria (e.g., why regional traditions matter in the first place for product quality). In line with discussions in economic sociology and cultural sociology, judgment devices are vital for the (e)valuation of commodities beyond the provision of information (Aspers 2018; Bessy and Chauvin 2013). Future studies could investigate the processes linking the use of judgment devices and demand even more closely by paying attention to the causal mechanisms involved in solving the interpretation problem. Researchers could collect experimental evidence complementing the correlational analysis with survey data.

Finally, the results show that the demand for fine wine is not directly related to social distinction once the use of judgment devices is accounted for. In line with Karpik's depiction, consumers of singular products appear to be highly reflexive and autonomous, making product choices based on the knowledge provided by judgment devices (Howland 2013). However, the engagement with judgment devices, in turn, correlates consistently and substantially with the social function and the normative expectation of wine consumption. Hence, processes of social distinction play a larger role for the engagement with judgment devices than for the actual purchase of fine wine. It is therefore not so much the "what" as the "how" of consuming singular products that is consequential for boundary making, social validation, and the accumulation of social prestige (Holt 1997). Judgment devices are an integral part of 
the culturally legitimate way to appropriate fine wine (Smith Maguire 2017). This suggests that social actors not only engage in the practice of acquiring knowledge on the quality of singular products to counter radical uncertainty, as Karpik argues. The users of judgment devices also link external rewards and symbolic group boundaries to the practice of fine wine consumption. They seem to have a sense for the rules of the game of fine wine consumption and the social consequences of using judgment devices (Strand and Lizardo 2015; Bourdieu and Wacquant 1996). In short, judgment devices are also "status anchoring devices" (Fourcade 2012, p. 527).

In conclusion, the analysis clearly confirms the merits of Karpik's theory for explaining the demand for singular products, but it also points to serious blindspots when it comes to processes of social distinction, prominently theorized in cultural sociology. I have focused on the differences between these approaches, but they also overlap and complement each other (Healy 2011; Kraemer 2017). Future research would strongly profit from putting the two theories into conversation. Whereas the economics of singularities focuses on the function of judgment devices in making markets for singular products possible, cultural sociology focuses on the function of judgment devices for the reproduction of social inequality. Whereas the economics of singularities emphasizes the reflexive capacities of actors to cope with radical uncertainty, cultural sociology emphasizes the social conditions for the use of judgment devices. Together, these theories could greatly improve our understanding of the intricate connections among consumption, judgment devices, markets, and social inequality in the age of singularization (Reckwitz 2020).

Supplementary Information The online version of this article (https://doi.org/10.1007/s11577-02100794-4) contains supplementary material, which is available to authorized users.

Acknowledgements Special thanks are due to Jörg Rössel, Gabriel Abend, Bernd Wurpts, Guy Schwegler, and Simone Pape. I am also grateful to the editors of the Kölner Zeitschrift für Soziologie und Sozialpsychologie and the anonymous reviewers for their helpful comments and suggestions. Part of this work originated during my time as a visiting scholar at the Max Planck Institute for the Study of Societies in Cologne. I am greatly indebted to my colleagues for the excellent discussions and the support I enjoyed there. Additionally, I want to thank Erwin Schenk for providing me with the necessary cultural capital to study wine. Finally, an earlier version of this paper was presented at the ESA RN 09 Economic Sociology Midterm Conference. Your judgments greatly improved the quality of this paper.

Funding The author(s) received no financial support for the research, authorship, and/or publication of this article.

Funding Open access funding provided by University of Luzern

Open Access This article is licensed under a Creative Commons Attribution 4.0 International License, which permits use, sharing, adaptation, distribution and reproduction in any medium or format, as long as you give appropriate credit to the original author(s) and the source, provide a link to the Creative Commons licence, and indicate if changes were made. The images or other third party material in this article are included in the article's Creative Commons licence, unless indicated otherwise in a credit line to the material. If material is not included in the article's Creative Commons licence and your intended use is not permitted by statutory regulation or exceeds the permitted use, you will need to obtain permission directly from the copyright holder. To view a copy of this licence, visit http://creativecommons.org/licenses/by/4. $0 \%$. 


\section{Declarations}

Conflict of interest P. Schenk declares no potential conflicts of interest with respect to the research, authorship, and/or publication of this article.

\section{References}

Akerlof, George A. 1970. The Market for "Lemons": Quality Uncertainty and the Market Mechanism. Quarterly Journal of Economics 84:488-500.

Aspers, Patrik. 2018. Forms of uncertainty reduction. Decision, valuation, and contest. Theory and Society 47:133-149.

Aspers, Patrick, and Jens Beckert. 2011. Value in Markets. In The Worth of Goods. Valuation and Pricing in the Economy, eds. Jens Beckert and Patrick Aspers, 3-38. Oxford/New York: Oxford University Press.

Beckert, Jens. 2007. The Social Order of Markets. SSRN Electronic Journal.

Beckert, Jens, Jörg Rössel and Patrick Schenk. 2016. Wine as a Cultural Product. Symbolic Capital and Price Formation in the Wine Field. Sociological Perspectives.

Bessy, Christian, and Pierre-Marie Chauvin. 2013. The Power of Market Intermediaries. From Information to Valuation Processes. Valuation Studies 1:83-117.

Beverland, Michael. 2006. The 'real thing'. Branding authenticity in the luxury wine trade. Journal of Business Research 59:251-258.

Bourdieu, Pierre. 2000. The rules of art. Genesis and structure of the literary field. Stanford: Stanford University Press.

Bourdieu, Pierre. 2007. Distinction. A social critique of the judgement of taste. Reprint. Cambridge, Mass.: Harvard University Press.

Bourdieu, Pierre, and Loïc J. D. Wacquant. 1996. Reflexive Anthropologie. Frankfurt am Main: Suhrkamp. Bruwer, Johan, Miranda Fong and Anthony Saliba. 2013. Perceived risk, risk-reduction strategies (RRS) and consumption occasions. Asia Pacific Journal of Marketing and Logistics 25:369-390.

Cameron, Adrian Colin, and P. K. Trivedi. 2010. Microeconometrics using Stata. College Station Tex.: Stata Press.

Carter, Elizabeth. 2017. For what it's worth. The political construction of quality in French and Italian wine markets. Socio-Economic Review 84:488.

Eloire, Fabien. 2010. Une approche sociologique de la concurrence sur un marché. Le cas des restaurateurs lillois. Revue française de sociologie 51:481.

Enders, Craig K. 2010. Applied missing data analysis. New York, NY, USA, London, UK: Guilford.

Felouzis, Georges, and Joëlle Perroton. 2007. Les « marchés scolaires ». Une analyse en termes d'économie de la qualité. Revue française de sociologie 48:693.

Fitzmaurice, Connor. 2017. How rosé became high class: Categorical divestment and evaluation. Poetics 61:1-13.

Fornell, Claes, and David F. Larcker. 1981. Evaluating Structural Equation Models with Unobservable Variables and Measurement Error. Journal of Marketing Research 18:39.

Fourcade, Marion. 2012. The Vile and the Noble: On the Relation between Natural and Social Classifications in the French Wine World. The Sociological Quarterly 53:524-545.

Franssen, Thomas, and Olav Velthuis. 2016. Making materiality matter. A sociological analysis of prices on the Dutch fiction book market, 1980-2009. Socio-Economic Review 14:363-381.

Frick, Bernd, and Robert Simmons. 2013. The impact of individual and collective reputation on wine prices. Empirical evidence from the Mosel valley. Journal of Business Economics 83:101-119.

Granovetter, Mark. 1985. Economic Action and Social Structure: The Problem of Embeddedness. American Journal of Sociology 91:481-510.

Healy, Keiran. 2011. Judgement and Distinction. Review Symposium. Lucien Karpik Valuing the Unique. The Economics of Singularities. Princeton, Princeton University Press, 2010. Socio-Economic Review: $1-5$.

Heintz, Bettina. 2016. „Wir leben im Zeitalter der Vergleichung.“ Perspektiven einer Soziologie des Vergleichs. Zeitschrift für Soziologie 45:305-323.

Holt, Douglas B. 1997. Distinction in America? Recovering Bourdieu's theory of tastes from its critics. Poetics 25:93-120. 
Howland, Peter J. 2013. Distinction by proxy. The democratization of fine wine. Journal of Sociology 49:325-340.

Hutter, Michael. 2011. Mapping a Continent—Valuing the Unique: The Economics of Singularities. Review Symposium. Lucien Karpik Valuing the Unique. The Economics of Singularities. Princeton, Princeton University Press, 2010. Socio-Economic Review:5-8.

Johnston, Josée, and Shyon Baumann. 2007. Democracy versus Distinction: A Study of Omnivorousness in Gourmet Food Writing. American Journal of Sociology 113:165-204.

Jourdain, Anne. 2010. La construction sociale de la singularité. Une stratégie entrepreneuriale des artisans d'art. Revue Française de Socio-Économie 6:13.

Karpik, Lucien. 2010. Valuing the Unique. The Economics of Singularities. Princeton: Princeton University Press.

Karpik, Lucien. 2011. What is the Price of a Scientific Paper? In The Worth of Goods. Valuation and Pricing in the Economy, eds. Jens Beckert and Patrick Aspers, 63-85. Oxford/New York: Oxford University Press.

Karpik, Lucien. 2013. Éléments de l'économie des singularités. In Traité de sociologie économique. Quadrige manuels, 2. ed., eds. Philippe Steiner and François Vatin, 163-206. Paris: PUF.

Kraemer, Klaus. 2017. Lucien Karpik: Mehr Wert. Die Ökonomie des Einzigartigen. In Schlüsselwerke der Wirtschaftssoziologie, eds. Klaus Kraemer and Florian Brugger, 507-514. Wiesbaden: Springer Fachmedien Wiesbaden.

Lamont, Michèle. 2012. Toward a Comparative Sociology of Valuation and Evaluation. Annual Review of Sociology 38:201-221.

Lamont, Michele, and Annette Lareau. 1988. Cultural Capital: Allusions, Gaps and Glissandos in Recent Theoretical Developments. Sociological Theory 6:153.

Lancaster, Kelvin J. 1966. A New Approach to Consumer Theory. Journal of Political Economy 74:132-157.

Lefèvre, Nicolas. 2015. Le marché du travail cycliste comme économie des singularités. Sociologie du travail 57.

Pape, Simone. 2012. Weinkonsum. Eine Studie zu sozialstrukturellen Determinanten und Lebensstilen im Feld des Weines. Wiesbaden: Springer Fachmedien Wiesbaden; Imprint: Springer VS.

Reckwitz, Andreas. 2020. Society of singularities. Cambridge, Medford MA: Polity.

Rodet, Diane. 2012. Des dispositifs de jugement pour et par les consommateurs? Les systèmes participatifs de garantie du commerce equitable, de l'agriculture biologique et des Amap. Revue Française de Socio-Économie 10:199.

Rössel, Jörg. 2007. Ästhetisierung, Unsicherheit und die Entwicklung von Märkten. In Märkte als soziale Strukturen, eds. Jens Beckert, Rainer Diaz-Bone and Heiner Ganssmann, 167-181. Frankfurt/New York: Campus Verlag.

Rössel, Jörg, and Jens Beckert. 2012. Quality Classifications in Competition: Price Formation in the German Wine Market. MPIfG Discussion Paper 12/3. Cologne: Max Planck Institute for the Study of Societies.

Rössel, Jörg, and Michael Hoelscher. 2017. Wer geht warum in die Oper? Sozialstruktur und Motive des Opernbesuchs. In Oper, Publikum und Gesellschaft, ed. Karl-Heinz Reuband, 241-258. Wiesbaden: Springer.

Rössel, Jörg, Patrick Schenk and Dorothea Eppler. 2016. The emergence of authentic products. The transformation of wine journalism in Germany, 1947-2008. Journal of Consumer Culture.

Schenk, Patrick. 2012. Rezension zu Lucien Karpik (2010): Valuing the Unique. The Economics of Singularities. Princeton: Princeton University Press. Kölner Zeitschrift für Soziologie und Sozialpsychologie 64:415-417.

Schenk, Patrick, and Jörg Rössel. 2012. Identität und Qualität im Weinfeld. In Feldanalyse als Forschungsprogramm, eds. Stefan Bernhard and Christian Schmidt-Wellenburg, 82-108. Wiesbaden: VS.

Schneider, Christoph. 1997. Präferenzbildung bei Qualitätsunsicherheit. Das Beispiel Wein, vol. 43. Berlin: Duncker \& Humblot.

Smith Maguire, Jennifer. 2010. Provenance and the liminality of production and consumption: The case of wine promoters. Marketing Theory 10:269-282.

Smith Maguire, Jennifer. 2017. Wine and China: Making Sense of an Emerging Market with Figurational Sociology. In The Social Organisation of Marketing, eds. John Connolly and Paddy Dolan, 31-59. Cham: Springer International Publishing.

Stigler, George J. 1961. The Economics of Information. Journal of Political Economy 69:213-225.

Strand, Michael, and Omar Lizardo. 2015. Beyond World Images. Sociological Theory 33:44-70. 
Verboord, Marc. 2010. The Legitimacy of Book Critics in the Age of the Internet and Omnivorousness: Expert Critics, Internet Critics and Peer Critics in Flanders and the Netherlands. European Sociological Review 26:623-637.

Zhao, Wei. 2008. Social Categories, Classification Systems, and Determinants of Wine Price in the California and French Wine Industries. Sociological Perspectives 51:163-199.

Patrick Schenk is a postdoctoral researcher at the University of Lucerne. The main focus of his research is economic sociology and consumption, cultural sociology, the sociology of morality, and the sociology of technology. He has published his research in Social Problems, Sociological Perspectives, Journal of Consumer Policy, Journal of Consumer Culture, Sustainability, and Berliner Journal für Soziologie. 